\title{
The state of IT Governance in Moroccan Public Sector
}

\author{
Mrs. Naima NAKABI ${ }^{1}$, Mr. Hatim TADILI ${ }^{2}$, Mr. Alami SEMAA ${ }^{3}$ \\ ${ }^{1}$ Hassan the first University, Faculty of Science and Technology \\ Settat, Morocco \\ ${ }^{2}$ Hassan the first University, Faculty of Science and Technology \\ Settat, Morocco \\ ${ }^{3}$ Hassan the first University, Faculty of Science and Technology \\ Settat, Morocco
}

\begin{abstract}
Information Technology (IT) is today essential to provide effective and efficient services. This reality extends to the Public Sector. The use of IT became decisive for organizations in the Public Sector and IT Governance recognized as an organizational capacity of great importance for IT strategic alignment and the delivery of business through IT.However, IT Governance requires different types of practices in the Public Sector. Our goal is to assess the IT Governance in organizations in the Moroccan Public Sector. Thus, the aim of this paper is to provide an overview of the current state of IT Governance practices in the Moroccan Public Sector. We are looking for the IT Governance mechanisms in place in terms of structures, processes, and relational mechanisms.
\end{abstract}

Keywords: IT Governance, Public Sector, survey, public value, Developing country, Morocco.

\section{Introduction}

Public Sector modernization becomes essential. The Public Sector is obliged to meet the ever-changing citizen needs. This reality increases the accountability of public decision-makers and requires a high level of transparency in the use of public resources and improved process performance.

In the Moroccan public sector, Information Systems (IS) become increasingly key levers of modernization and egovernment. Their main challenges are the project and portfolio management, the rationalization of the application, the integration of new technologies and the guarantee of openness and security.

The Moroccan Public Sector must rely on IS to achieve efficiency, increase performance and expand provided services. To achieve these objectives and enable IS to create value within these organization, effective IT Governance is required. Our goal is to know which IT Governance practices are implemented in the Moroccan public sector.

\section{Public sector specificities and constraints}

\subsection{Public Sector specificities}

The Public Sector is a great economy factor, in most economies, public spending represents a significant share of gross domestic product, and the Public Sector organizations are important employers and the first player in the capital market. In this sector, a good governance should base on better decision-making, efficient use of resources, and strengthening of responsibilities. The goal is to improve performance, increase efficiency, improve service delivery, and thus maximize results and improve the quality of citizen's life.

\section{a) Public Value}

Understanding the notion of value in the Public Sector helps to understand better the objectives of public organizations and provides guidelines for good governance.

According to Moore, the founder of the Public Value Theory, Public value asks public officials to consider the benefits and costs of public services not only in terms of dollars and cents, but also in terms of how government actions affect important civic and democratic principles such as equity, liberty, responsiveness, transparency, participation, and citizenship. The Public Value implies:

- Economic growth,

- The increase of the share capital,

- Cultural development, 
- Improving safety

- Improvement of health and school services

b) Public performance

Public performance is the ability to satisfy needs or expectations of general interest, explicit or not, at a cost considered acceptable or "just" by the customer or the recipient "value for money". The public performance combined the following concepts:

- Efficiency is the ratio between the results obtained and the resources involved.

- Effectiveness is the relationship between the results achieved and the objectives.

- Coherence is the relationship between objectives and means.

- Quality is the right answer to the expectations of the beneficiaries

- Satisfaction is the relationship between needs and outcomes.

- Relevance is the relationship between needs and objectives.

The result is the expected result vs the result perceived from the point of view of the beneficiaries or the desired result vs result achieved from the point of view of the service providers. Measuring public performance is appropriate for organizations delivering identifiable goods and services. However, will be more difficult for organizations that deliver diffuse services, such as diplomacy, preservation of the environment, regulatory activities.

\section{c) Public Quality}

In the Public Sector, we have to define a quality policy as will as the quality level to achieve, beneficiaries and their expectations, objectives to pursue and the available resources. Organizations should review regularly these objectives.

Quality in the Public Sector must take into consideration improvements to bring to citizens, working conditions, work organization, management and consensus on objectives.

According to PricewaterhouseCoopers, We can regroup the citizen's required improvements into seven main points: Processing time, commitments to citizen expectations, value of services provided, single access window. Given choice of Different distribution channels, dedicated service.

\subsection{Public Sector Constraints}

The policy and the accelerated pace of reforms strongly affect the public sector. The policy decides, sometimes in short deadlines, and far from efficiency and feasibility, which changes to implement. Therefore, the public sector must challenge a set of constraints:

- Consumers expecting of perfect service quality;

- Constraints of Budget delaying improved efficiency;

- $\quad$ Equity demands.
- Strong need for treatment security, data confidentiality, access traceability, internal control and risks protection despite the openness context and information sharing;

- Media and social movements encouraging international of public services;

- The difficulty to take decisions. Although studies can support a path, decisions often take another one.

\section{IT Governance in the Public Sector}

Implementing IT Governance is always a challenge for organizations within the Public Sector. Current approaches focus on characteristics specific to the market such as profitability and competition. They cannot be suitable to the Public Sector. [Moore, 1994; Weill \& Ross, 2004].

A Little research in this area and the way to implement the IT Governance in this sector is still ambiguous [Ali \& Green, 2007; Weill \& Ross, 2004]. The purpose and legitimacy of the Public Sector and its fundamental objective are to create public value and improve the quality of life. IT is today essential to deliver efficient and effective services. Given the particularities and constraints of the Public Sector, the IT Governance requires different types of practices.

In the Public Sector, we need a good governance, it based on:

- Better decision-making;

- Effective use of resources;

- Strengthening of responsibilities;

Weil and Ross (2004) and Campbellet al. (2009) identified difficulties that delay the implementation of IT Governance in the Public Sector, namely:

- Difficulty in measuring public value and performance;

- Computerized coproduction architecture between public organizations;

- The diversity of interests due to stakeholder diversity. Suomi and Tähkäpää (2004) point out that reconciling the interests of different stakeholders is the basis of the concept of public value and therefore a determining factor in IT Governance. In addition, Campbell et al. (2009) identified other constraints related to Public Sector such as the multitude of objectives, rigid regulation, and lack of motivation and high level of bureaucracy.

Therefore, IT Governance is the responsibility of the officers and the board of directors. In the Public Sector, it bases on determinant factors:

- Set up an IT leadership authority granted to the IT manager with a clear definition of his authorities and responsibilities.

- Define the organizational structure of the organization in terms of IT functionality and IT subordinates while defining the limits and separations between the functions of the IT and the business. 
- Clear decision-making processes in terms of portfolio management, required IT investments. Decision-making in the public sector is an important challenge given the diversity of stakeholders and the complexity of the hierarchical structures and, at times, the obligation to impose solutions based on the economy or politics.

In addition, there are two other factors related to the resources management namely the competency management and performance measurement.

\subsection{IT performance}

Literature highlights various items we can use to assess IT performance in organizations. In general, IT performance consists of:

1- Strategic alignment between IT and business

2- IT value delivery

3- Resource optimization in delivering IT services

4- IT cost effectiveness

5- Business flexibility through IT

6- Qualifications of IT and business staff for the proper exercise of IT responsibilities.

\section{The Moroccan Case}

In Moroccan Public Sector, Organizations need to define the critical success factors for effective IT Governance. They must take into consideration the immature state of governance and the constraints on IT resources, knowledge and culture. Our aim is to discuss a new approach, which will facilitate the IT Governance implementation in the Moroccan Public Sector.

\subsection{IT Governance in practice}

Starting from the definition of IT Governance given by Van Grembergen as "The organizational capacity exercised by the board of directors, the executive management and the IT managers to implement and control the IT strategy and ensure Business / IT alignment ". In practice, as shown in figure 1, IT Governance is a combination of three components: processes, structures, and relational mechanisms. Each component is essential to the success of the IT Governance (Weill and Woodham 2002 Van Grembergen et al 2004).

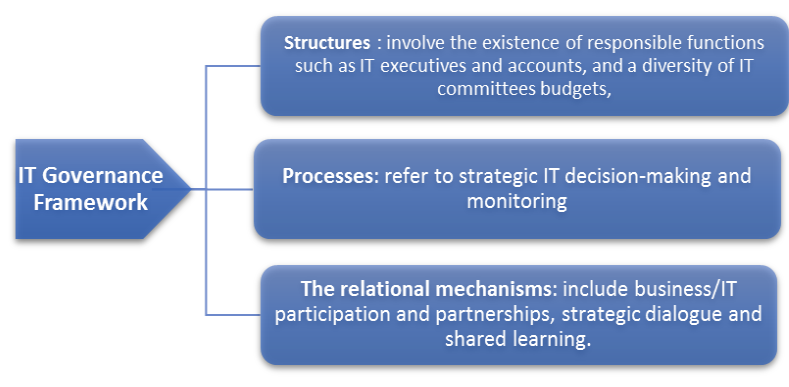

Fig. 1 IT Governance Framework

\section{The State of IT Governance}

\subsection{Methodology}

In order to describe the IT Governance practices in the Moroccan public sector and discover problems of noneffective IT Governance in this Sector, we had used a quantitative research methodology through a survey questionnaire including 41 questions. Our aim is to measure the extent of IT Governance practices and this approach was necessary to carry out a holistic investigation.

This work was done between September 2016 and February 2017 with both IT and business profile from organizations in the public sector in Morocco.

The questionnaire consists mainly of closed-ended, multiplechoice questions on IT Management, IT governance Structures, processes, and relational mechanisms.

\subsection{Data Analysis and Discussion}

In order to evaluate the activities of the IT Department in the public sector in Morocco, we were first interested in measuring the IT Management.Afterward, we evaluate the presence of the IT Governance structures, IT Governance processes, and IT Governance relational mechanisms.

\section{a) IT Management}

The management covers all activities of monitoring, audit, developing IT strategy and project portfolio management. Our aim is to measure the IT department ability to anticipate and take consideration of technological developments, the ability to identify areas of internal progress, which mean audit, and finally, the ability to manage, and projects and Portfolio. 
Table 1: Summary of IT Management activities in the studied organizations

\begin{tabular}{|c|c|c|}
\hline \multicolumn{3}{|c|}{ Activities for IT Management } \\
\hline \multicolumn{3}{|c|}{ IT strategic plan } \\
\hline 1 & $\begin{array}{l}\text { Define the IT strategy } \\
\text { and the objectives to } \\
\text { be achieved }\end{array}$ & $\begin{array}{l}\text { In more than } 80 \% \text { of the cases, the IT strategy is } \\
\text { elaborated by the IT Department and in } 57 \% \text {, it } \\
\text { is communicated to the business for opinion }\end{array}$ \\
\hline 2 & $\begin{array}{l}\text { Strategic alignment } \\
\text { between business and } \\
\text { IT }\end{array}$ & $\begin{array}{l}\text { The IT strategy is integrated into the Business } \\
\text { strategy in } 37.9 \% \text {. In } 31 \% \text {. The IT strategy is } \\
\text { elaborated and validated with business. In the } \\
\text { remaining cases, the IT strategy is not integrated } \\
\text { into the Business strategy. }\end{array}$ \\
\hline 3 & $\begin{array}{l}\text { IT projects } \\
\text { Management }\end{array}$ & $\begin{array}{l}\text { The IT Department is recognized as a Service } \\
\text { Center in more than } 76 \% \text { of cases and better, in } \\
20 \% \text { cases as a Source of Value Creation. Only } \\
\text { in less than } 4 \% \text {, the IT department is recognized } \\
\text { as a cost center. }\end{array}$ \\
\hline 4 & $\begin{array}{l}\text { Ensuring strategic } \\
\text { Management }\end{array}$ & $\begin{array}{l}\text { Post project indicators are tracked and } \\
\text { monitored systematically and regardless of } \\
\text { project type in only } 12.9 \% \text {. In more than } 54 \% \text { of } \\
\text { cases, monitoring and control are absent. }\end{array}$ \\
\hline \multicolumn{3}{|c|}{ IT Performance Management } \\
\hline 1 & Manage Performance & $\begin{array}{l}\text { The IT Department produces and disseminates } \\
\text { dashboards and performance indicators: } \\
\text { - In } 34.5 \% \text {, not produced } \\
\text { - In } 31 \% \text {, produced but not analyzed. } \\
\text {-In } 34.5 \% \text {, produced and analyzed. }\end{array}$ \\
\hline 3 & Manage costs & $\begin{array}{l}\text { In more than } 41 \% \text {, there is no process for } \\
\text { assessing and reviewing IT investments. But in } \\
\text { more than } 38 \% \text {, IT investments are revised only } \\
\text { after an IT or Business problem. The ideal case } \\
\text { was IT investments are reviewed on a regular } \\
\text { basis is less than } 20 \% \text {. }\end{array}$ \\
\hline \multicolumn{3}{|c|}{ Monitoring and audit } \\
\hline 1 & $\begin{array}{l}\text { Choosing } \\
\text { internationally } \\
\text { recognized for IT } \\
\text { quality }\end{array}$ & $\begin{array}{l}\text { Best practices are non-existent or not applied in } \\
64.3 \% \text { of cases }\end{array}$ \\
\hline 2 & $\begin{array}{l}\text { Implementing } \\
\text { regular IT audit }\end{array}$ & $\begin{array}{l}\text { Internal audit are carried out periodically in } \\
51.7 \% \text { and in } 41.4 \% \text {, no audit No internal } \\
\text { control is performed }\end{array}$ \\
\hline 3 & $\begin{array}{l}\text { Implement an IT } \\
\text { benchmarking } \\
\text { approach }\end{array}$ & $\begin{array}{l}\text { It is not widely practiced, in more than } 75 \% \text {, no } \\
\text { process exists. }\end{array}$ \\
\hline
\end{tabular}

b) IT Governance structures:

We look for how the IT function organized in the most organizations of the Moroccan Public Sector.

Structures involve also the clear definition of roles and responsibilities and presence of a diversity of IT/business committees.

The survey displays that the IT department is at the same level as other departments in under fifty cases. In these cases, the Chief Information Officer (CIO) reports directly to the senior management. In the other cases, the IT department attached to another entity.

In 55\% of the cases, the Roles and Responsibilities business and IT are documented and we notice that The CIO is exclusively responsible for the IS in more than $50 \%$ of cases.
Only in less than $20 \%$ of cases, business and IT are mutually responsible for the Information System and its evolution. Regarding the presence of committees, the most of them are present. Fig 2 shows the percentage of the presence of each one.

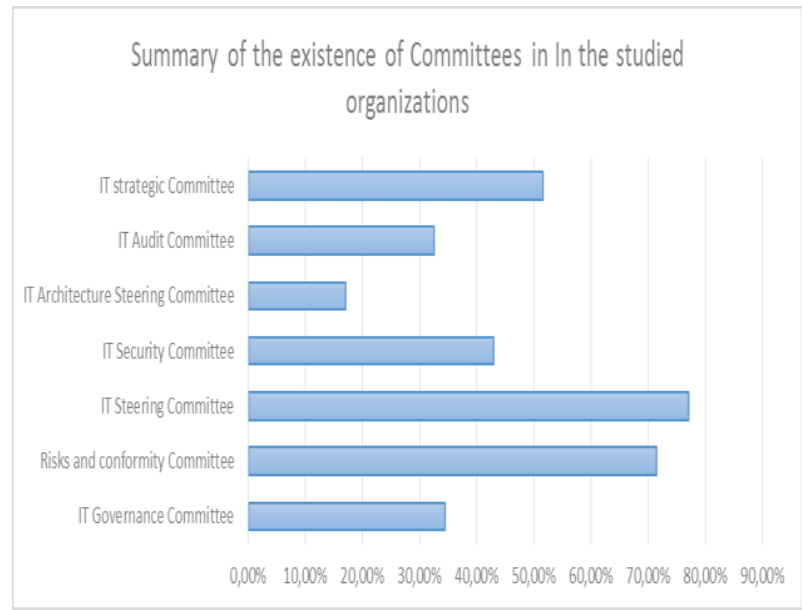

Fig. 2. Summary of the existence of Committees in the studied organizations

c) IT Governance Processes

Processes refer to the strategic IT decision-making and monitoring. The first process we evaluate is the development of an IT strategic plan. We find that, in more than sixty per cent cases, the IT plan exists and validated with business.

Other processes like Project priority management, disseminating scorecards and performance measurement indicators exist in the third of Cases.

In additional, we find that processes relative to SLAs practices, analysis and benchmarking of IT cost (reassignment / re-invoicing), evaluation of IT investments are not used.

Fig 3 shows the use of the IT governance Processes in the studied organizations.

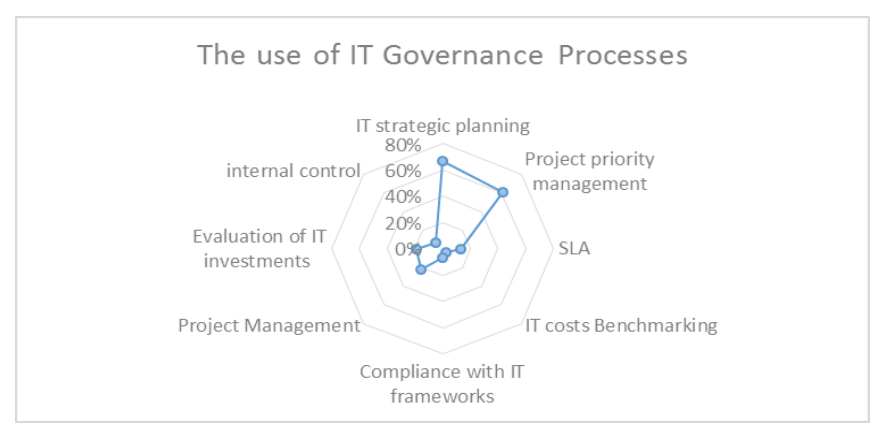

Fig. 3. The use of the IT Governance Processes in the studied organizations 


\section{d) IT Governance Relational Mechanisms:}

Even if structures and processes are in place, organizations need in additional some relational mechanisms to attain and sustain business and IT alignment. We have grouped these mechanisms as follows:

- Shared understanding of business / IT Goals We note that in more than $62 \%$ of the cases, the managers of the profession have a limited knowledge of the IT environment. The IT Department understands organization business model in the most cases. Except that we realize that, teams do not share systematically this understanding. The survey shows that more than $41 \%$ cases, there is not a common framework between the Business and IT. However, some principles and procedures are in preparation in $41 \%$ of cases.

- Informal meetings between business and IT

The communication between Business and IT tend to be formal and rigid. Stakeholder's familiarity and comfort in informal meetings are not evident. The dialogue between business and IT takes place mostly during meetings or planned committees. In only $13.8 \%$ of the cases, the IT department has a plan of communication adapted to projects in progress.

- Knowledge management

Sharing knowledge rarely occurs in organizations survived. Some structures of Knowledge Management begins to be created in more than $37 \%$. In more than $18 \%$, Knowledge sharing is formalized in the complete organization.

- Business/IT job rotation

Possibilities of business /IT job rotation do not occur in most cases or sometimes within the organization. The fig. 3 below shows the distribution in the studied organizations.

- Business/IT co-location

Given the particular nature of the organizations studied, where all departments are centralized. We have found that most often, the business and IT teams are co-located on common projects.

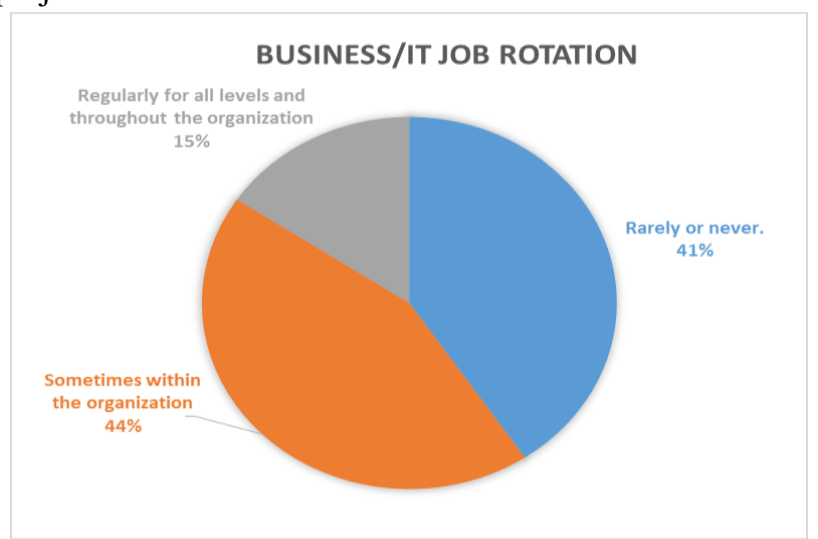

Fig. 4. Distribution of Business/IT job rotation in the studied organizations
Table 2: Summary of IT Governance structures, processes and relational mechanisms in the studied organizations

\begin{tabular}{|c|c|c|}
\hline \multicolumn{3}{|c|}{ IT Governance Structures } \\
\hline 1 & IT function & $\begin{array}{l}\text { In only } 45 \% \text { of cases, the IT department } \\
\text { is attached to the board. And in only } \\
35.5 \% \text {, the IT director is a part of the } \\
\text { executive management and report } \\
\text { directly to the CEO in less than } 46 \% \text {. }\end{array}$ \\
\hline 2 & $\begin{array}{l}\text { Roles and } \\
\text { Responsibilities }\end{array}$ & $\begin{array}{l}\text { In more than } 51 \% \text { of cases, IT, and } \\
\text { business Role's Responsibilities' are } \\
\text { documented. }\end{array}$ \\
\hline 3 & Committees & $\begin{array}{l}\text { Several committees exist to support the } \\
\text { IT functions in surveyed organizations. } \\
\text { The IT steering committee exists in } \\
\text { more than } 77.8 \% \text {. Contrariwise, the IT } \\
\text { Architecture Steering Committee exists } \\
\text { only in less than } 15 \% \text {. }\end{array}$ \\
\hline \multicolumn{3}{|c|}{ IT Governance Processes } \\
\hline 1 & Strategic IT Planning & $\begin{array}{l}\text { The IT strategy is integrated into the } \\
\text { organization's planning process in more } \\
\text { than } 67 \% \text { of cases. }\end{array}$ \\
\hline 2 & $\begin{array}{l}\text { IT Governance } \\
\text { frameworks }\end{array}$ & $\begin{array}{l}\text { Best practices are non-existent or not } \\
\text { applied in } 64.3 \% \text { of cases }\end{array}$ \\
\hline 3 & Prioritization of projects & $\begin{array}{l}\text { In more than the third of cases, this } \\
\text { approach is not used. }\end{array}$ \\
\hline 4 & $\begin{array}{l}\text { Service Level } \\
\text { Agreements (SLAs) } \\
\text { Activity Based } \\
\text { Costing/Budgeting } \\
\text { ROI Calculation and } \\
\text { measurements }\end{array}$ & Not widely practiced \\
\hline \multicolumn{3}{|c|}{ IT Governance relational mechanisms } \\
\hline 1 & $\begin{array}{l}\text { Shared understanding } \\
\text { of business/IT goals }\end{array}$ & $\begin{array}{l}\text { A shared understanding of business and } \\
\text { IT goals is generally more current at the } \\
\text { top management level. Business issues } \\
\text { are explained to teams when is a } \\
\text { prerequisite for a project achievement. }\end{array}$ \\
\hline 2 & Informal meetings & $\begin{array}{l}\text { The communication between Business } \\
\text { and IT tend to be formal and rigid }\end{array}$ \\
\hline 3 & $\begin{array}{l}\text { Knowledge } \\
\text { management }\end{array}$ & $\begin{array}{l}\text { Not widely practiced, but Some } \\
\text { structures of begins to be created. }\end{array}$ \\
\hline 4 & Business/IT job rotation & Not widely practiced \\
\hline 5 & Business/IT co-location & $\begin{array}{l}\text { Systematically given the nature of } \\
\text { studied organizations. }\end{array}$ \\
\hline
\end{tabular}

\section{Conclusion and future work}

IT governance based on decisive factors namely: (i) setting up an IT leadership authority that must be granted to the CIO with a clear definition of his authorities and responsibilities. (ii) Defining organization's structure in terms of IT functionality and IT subordinates and describing limits and separations between Business/IT functions. (iii) Definition of clear decision-making processes in terms of portfolio management, the necessary IT investments. Decision-making in the public sector is an important challenge. The diversity of stakeholders, the complexity of the hierarchical structures, the economic and 
politics obligation, the difficulty of resources management and performance measurement all influence decision-making in the sector. Aware of these difficulties especially in a developing country such Morocco, we studied IT Governance practices in organizations of the Moroccan public Sector. We conclude that many organizations are beginning to implement IT Governance practices. We note that IT Governance Structures are implemented in the main cases. For IT Governance Processes, we note that IT frameworks are not applied and specific processes like Service Level Agreements (SLAs), Activity Based Costing, ROI calculation, and measurements are not widely practiced. The same thing for IT relational mechanisms which still not common for all organization. We understand that improvement continues to being done with the emergence of e-government, the data are in perpetual change. In otherwise, some organizations are still in computerizing their services. Surely, IT Governance approach will take the time to emerge. We continue to pursue our research with a vision to provide a critical success factors framework for implementing effective IT governance in the Moroccan public sector organizations. Our aim is to assist organizations in the sector to focus on practices that have a major effect on effective IT governance implementation. The goal is to improve public service delivery of Moroccan Public Service.

\section{References}

[1] Autissier, D., \& Delaye, V. (2008). Measures la performance du système d'information. Paris: Eyrolles.

[2] Moore, M. H. (1994). Public value as the focus of the strategy. Australian Journal of Public Administration, 53(3), 296-303. http://dx.doi.org/10.1111/j.1467-8500.1994.tb01467.x

[3] Weill, P. \& Ross, J.W. IT Governance: How Top Performers Manage IT Decision Rights for Superior Results, Harvard Business School Press, 2004.

[4] Suomi, R., \& Tähkäpää, J. (2004). Governance structures for IT in the Health Care industry. In W. Van Grembergen (Ed.), Strategies for information technology governance (pp. 357-381). Hershey: Idea Group Publishing.

[5] Ali, S., \& Green, P. (2007). IT governance mechanism in public sector organizations: An Australian context. Journal of Global Information Management, 15(4), 41-63. http://dx.doi.org/10.4018/jgim.2007100103

[6] Grembergen, W. V., Haes, S. D., \& Guldentops, E. (n.d.). Structures, Processes and Relational Mechanisms for IT Governance. Strategies for Information Technology Governance.

[7] D., \& M. (n.d.). Establishing good IT governance in the public sector, from http://www.mckinsey.com/ /media/McKinsey/dotcom/client_servi ce/Public\%20Sector/PDFS/McK\%20on\%20Govt/IT/TG_it_governance. ash $x \& \mathrm{p}=\mathrm{DevEx}, 5086.1$

[8] Stratégie Nationale pour la Société de l'Information et de ... (n.d.), from http://www.egov.ma/sites/default/files/Maroc\%20Numeric\%20201 3.pdf\&p=DevEx,5083.1

[9] Campbell, J., Mcdonald, C., \& Sethibe, T. (2010). Public and Private Sector IT Governance: Identifying Contextual Differences. Australasian Journal of Information Systems,16(2). doi:10.3127/ajis.v16i2.538

Naima NAKABI is an IT Engineer graduated from INPT (2003) (National Institute of Posts and Telecommunications), and Ph.D. candidate at FST. Her research focuses on IT Governance and IT frameworks. She is a project engineer at the Ministry of Agriculture of the Kingdom of Morocco since 2004. His work has appeared in International Journal of Computer Science Issues.

Hatim TADILI is a Ph.D. student in Cloud Computing in the Faculty of Science and Technology, Morocco. Currently working at the National Office of Electricity and Water as an IT infrastructure responsible. His main research interests are Cloud Computing, governmental technology, and public services. His work has appeared in International Journal of Computer Science Issues.

ALAMI SEMAA is a Ph.D. in the Hassan the first University, Faculty of Science and Technology in Settat, Morocco. He is a qualified professor in electrical engineering. 